Cronfa - Swansea University Open Access Repository

This is an author produced version of a paper published in :

Geoderma

Cronfa URL for this paper:

http://cronfa.swan.ac.uk/Record/cronfa21410

\title{
Paper:
}

Mastrolonardo, G., Rumpel, C., Forte, C., Doerr, S. \& Certini, G. (2015). Abundance and composition of free and aggregate-occluded carbohydrates and lignin in two forest soils as affected by wildfires of different severity.

Geoderma, 245-246, 40-51.

http://dx.doi.org/10.1016/j.geoderma.2015.01.006

This article is brought to you by Swansea University. Any person downloading material is agreeing to abide by the terms of the repository licence. Authors are personally responsible for adhering to publisher restrictions or conditions. When uploading content they are required to comply with their publisher agreement and the SHERPA RoMEO database to judge whether or not it is copyright safe to add this version of the paper to this repository. http://www.swansea.ac.uk/iss/researchsupport/cronfa-support/ 


\section{Abundance and composition of carbohydrates and lignin in two forest soils affected by wildfires of different severity}

5 Giovanni Mastrolonardo ${ }^{1,2}$, Cornelia Rumpel $^{2}$, Claudia Forte $^{3}$, Stefan H. Doerr ${ }^{4}$, Giacomo Certini ${ }^{1}$

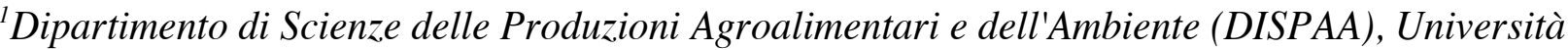
degli Studi di Firenze, Piazzale delle Cascine 28, 50144 Firenze, Italy.

${ }^{2}$ CNRS; nstitute of Ecology and Enviroment Paris (IEES, UMR Université Paris VI et XII - CNRS

- IRD), Campus AgraParisTech, Thiverval-Grignon, France.

${ }^{3}$ Istituto di Chimica dei Composti OrganoMetallici (ICCOM), UOS Pisa, CNR, Pisa, Italy

${ }^{4}$ Geography Department, Swansea University, Singleton Park, Swansea SA28PP, UK.

Corresponding author G. Mastrolonardo, tel: +39 055522 6509; fax: +39 0555226477

E-mail address: giovanni.mastrolonardo@gmail.com

Keywords: wildfires; soil organic matter; non-cellulosic neutral sugars; lignin; soil density fractions; ${ }^{13} \mathrm{C} \mathrm{NMR}$.

Fire is a major ecological factor, affecting more land surface that any other natural disturbance (Lavorel et al., 2007; Scott et al., 2014). Soils are affected by many direct and indirect consequences of fire, which can alter the physical, mineralogical, chemical and biological properties of soil, either temporarily or permanently (Bento-Gonçalves et al., 2012; Certini, 2005; Neary et al., 1999). The organic component of soil is the one most affected by fire, in terms of both content and composition (González-Pérez et al., 2004; Certini et al., 2011). The assessment of the 
overall effect of fire on soil organic matter (SOM) is a complex task because burnt soils are generally a patchwork of areas affected to different degrees by burning. For example, besides the factors correlated with site, soil and vegetation features, fire effects on SOM depend on the degree and duration of heating, the availability of oxygen and the type of combustion (smouldering or flaming), which may lead to different SOM transformations (González-Pérez et al., 2004; Rumpel et al., 2007; Shakesby and Doerr, 2006). Most often fire causes a substantial reduction of the organic matter stock in the litter layer (Bento-Gonçalves et al., 2012; Certini et al., 2011; Nave et al., 2011). There are, however, contrasting results in the literature about quantitative changes in the mineral soil. For instance, meta-analyses by Johnson and Curtis (2001) and Nave et al. (2011), have contrasting outcomes, concluding that in the short-term the A horizon does experience, respectively, a significant fire-induced increase and decrease in $\mathrm{C}$ content. However, divergent results from different studies can arise from methodological differences, related to sampling strategy, including soil depth interval considered and time elapsed since fire, local conditions, as for example vegetation/climate type.

In terms of SOM quality, the reactions that take place during combustion, $e . g$. dehydration, dehydrogenation, volatilisation of nitrogenous compounds, decarboxylation, demethylation, demethoxylation, cyclisation and polycondensation (Hernàndez et al., 1997; Knicker, 2007), can substantially change the composition of the parent material. Charcoal formation is the most common outcome of wildfires and essentially represents the temperature and oxygen-depletion dependent transformation of the organic compounds into highly recalcitrant aromatic structures (Alexis et al., 2010). Once incorporated into the soil, charcoal may resist decomposition for centuries or even millennia, thereby sequestering carbon (Egli et al., 2012; Kuhlbusch and Crutzen, 1995; Schmidt and Noack, 2000). Carbohydrates are believed to be among the most fire-affected components of SOM (Certini, 2005; González-Pérez et al., 2004; Knicker et al., 2006). On this basis, Martín et al. (2009) proposed the ratio of carbohydrates to total SOM as an index of fire impact on SOM quality. Such an index allows, in principle, also differentiating between low- and 
high- soil burn severity wildfires. Lignin, which, after carbohydrates, is the second most abundant component of plant residues in terrestrial ecosystems, is rather resistant to fire and is totally oxidised only at $400-450{ }^{\circ} \mathrm{C}$ (DeBano, 1991 ; Kuo et al., 2008). Nevertheless, despite the high heat resistance of its backbone (Knicker, 2011; Sharma et al., 2004), lignin is affected by fire at much lower temperatures $\left(200-250{ }^{\circ} \mathrm{C}\right.$ ) in terms of the distribution of phenols (Certini et al., 2011; Nocentini et al. 2010; Rumpel et al., 2007). Therefore, the composition of SOM regarding lignin and phenols has potential as an indicator of fire occurrence and severity. Quantifying post-fire lignin phenols and sugars in soil might be useful to evaluate the wider impact of fire on soil quality. In the mineral soil, the effects of fire are usually confined to the top few $\mathrm{cm}$ because of the low thermal conductivity of both minerals and pore spaces. Nonetheless, in several studies reporting on fire impacts, soil has been sampled to rather substantial depths, which is likely to have resulted in the dilution of the investigated fire effects.

In this study, we investigated the top $2.5 \mathrm{~cm}$ of mineral soil of two forests located in Italy and Australia, which have been affected by recent wildfires of moderate and extreme severity, respectively. The purpose of using two contrasting sites in terms of forest type and fire severity was to assess changes to SOM quality resulting directly from the fire and explore their implications. We focused particularly on the non-cellulosic neutral sugars, those digested by trifluoroacetic acid (TFA), and lignin-derived phenolic monomers, those released by cupric oxide $(\mathrm{CuO})$ oxidation. We further analysed the distribution of density fractions in SOM and the composition of such fractions. The changes SOM experienced at the two sites were compared to relate them to fire severity, hypothesising common fire-related alterations in SOM, mainly driven by fire severity.

\subsection{Study sites}


The study sites are Orentano (hereafter called OR), $30 \mathrm{~km}$ east of Pisa, Tuscany, Central Italy, and Mount Gordon (hereafter called MG), near Marysville, in the Victoria State, south-east Australia (Fig. 1; Table 1).

Orentano (OR), $20 \mathrm{~m}$ a.s.1., has a mean annual precipitation of $893 \mathrm{~mm}$ and a mean annual temperature of $14.3^{\circ} \mathrm{C}$. The vegetation cover is a mixed forest of Downy oak (Quercus pubescentis Willd) and Maritime pine (Pinus pinaster Aiton) with a rich understory of common fern (Pteridium aquilinum L.) and Rubus spp. Soils formed on sand and stony lacustrine deposits - where quartz is largely dominant and chlorite, illite, kaolinite, and goethite are accessory minerals - and are classified as Haplic Skeletic Acrisols according to the World Reference Base for Soil Resources (IUSS Working Group WRB, 2014). In July 2011, an area of 3.3 ha underwent a wildfire of moderate to high severity, based on the visual scale of litter and vegetation consumption proposed by Chafer et al. (2004). Most of the tree stems were still standing after the fire and were partly or totally scorched. The soil was covered entirely by charcoal and ash, with no or very little uncharred litter remaining. Soil sampling was carried out three days after the fire, on both the burnt area (coordinates WGS84: 434ㄱ'22.82"N, 10³9'52.30"E) and an adjacent (50 meters away) unburnt area having the same characteristics of the burnt one prior to fire occurrence, thus used as control. At Mount Gordon (MG) the sampling area is located $530 \mathrm{~m}$ a.s.1., where mean annual precipitation is $670 \mathrm{~mm}$ and mean annual temperature is $13{ }^{\circ} \mathrm{C}$. The site was chosen because it represented an end-member in terms of fire severity. The sadly famous 'Black Saturday' fire, which involved also MG, in early February 2009, burned some 450,000 ha of eucalypt forest causing the loss of 173 lives (Royal Commission, 2009). Average fire-line intensity is estimated to have exceeded 70,000$80,000 \mathrm{~kW} \mathrm{~m}^{-1}$, which is amongst the highest ever reported in Australia (Royal Commission, 2009). Such an extreme intensity was promoted by particularly extreme weather conditions, such as wind speeds up to $100 \mathrm{~km} \mathrm{~h}^{-1}$ and air temperatures even exceeding $45^{\circ} \mathrm{C}$. Fuel loads were very high, since the forest had not experienced a major fire since 1939 (fuel load, including the litter, amounted to 25-40 $\mathrm{Mg} \mathrm{ha}^{-1}$ ), and fuel moisture was very low (3-4\%) because of prolonged drought 
conditions (McCaw et al., 2009). The sampling site (37³1'56.30"S, $\left.145^{\circ} 43^{\prime} 17.14^{\prime \prime} \mathrm{E}\right)$ is an

Eucalyptus spp. mixed forest $3 \mathrm{~km} \mathrm{SW}$ of Marysville on the road to Narbethong. The fire removed all ground fuel, green vegetation and woody stems $<10 \mathrm{~mm}$ in diameter; accordingly, fire severity was classified as extreme, based on the classification of Chafer et al. (2004). A long unburnt site last burned by wildfire in 1939 - was selected as control, approximately $3 \mathrm{~km} \mathrm{NW}$ of Narbethong $\left(37^{\circ} 32^{\prime} 54.10^{\prime \prime} \mathrm{S}, 145^{\circ} 37^{\prime} 37.30 " \mathrm{E}\right)$. This site is $8.5 \mathrm{~km}$ away from the burnt site and as much as possible similar to the latter in terms of all environmental conditions, soil included. Soils of the area formed on sandy Devonian sediments - where quartz is largely prevailing and the clay fraction comprises vermiculite, illite, and kaolinite - and are classified as Dystric Humic Cambisols according to the World Reference Base for Soil Resources (IUSS Working Group WRB, 2014). Sampling was performed in April 2009, two months after the fire and following some light rainfall, but before the more intense precipitation of winter had caused significant ash removal via erosion.

\section{$2.2 \quad$ Soil sampling}

At both study sites, OR and MG, the sampling involved four parallel $20 \mathrm{~m}$ transects, laid out $5 \mathrm{~m}$ apart, at $5 \mathrm{~m}$ intervals. Twenty mineral soil samples were taken at each site down to $2.5 \mathrm{~cm}$, after carefully removing the ash, charcoal, or any litter layer by a brush. In both burnt areas, ten samples of charcoal particles were randomly collected in $40 \times 40 \mathrm{~cm}$ plots.

\subsection{Physico-chemical properties}

Soil $\mathrm{pH}$ was measured potentiometrically using deionised water to soil ratio of 5:1, while particle size analysis was performed according to the hydrometer method. Total $\mathrm{C}$ and $\mathrm{N}$ contents and stable carbon isotopic composition of the fine earth (the less than $2 \mathrm{~mm}$ soil fraction) and charcoal were measured by a Carlo Erba NA1500 elemental analyser coupled to an isotope ratio mass spectrometer (Micromass-Optima). $\delta^{13} \mathrm{C}$ isotope abundance was reported in per mil (\%o) relative to the Pee Dee Belemnite standard (PDB). 


\subsection{Density fractionation}

132

Density fractionation was carried out on two soil samples per site, both obtained combining equal aliquots of ten samples of fine earth. The procedure was based on the method of Golchin et al. (1994), modified according to Sohi et al. (2001) and Cerli et al. (2009). This procedure allows different fractions, related to the spatial arrangement and interactions of organic compounds with minerals, to be separated (Cerli et al., 2012). The method requires a sodium polytungstate (NaPT) solution adjusted at a specific density to isolate a free light fraction (f-LF). By addition of the same solution to the precipitated material, followed by ultrasonic dispersion to break down the aggregates, the occluded light fraction (o-LF) is separated from the heavy fraction (HF), the latter fraction mainly comprising minerals. We performed preliminary trials in order to determine the most suitable density cut off and sonication energy for the fractionation. We first used the density and sonication intensities most commonly found in the literature, i.e. 1.6 and $1.8 \mathrm{Mg} \mathrm{m}^{-3}$ and 100 and $300 \mathrm{~J} \mathrm{~cm}^{-3}$, respectively (Cerli et al., 2009, 2012; Golchin et al., 1997; Kiem and KögelKnabner, 2003), wit the ultrasonic energy being calibrated calorimetrically according to Schmidt et al. (1999). Based on the criterion of the highest SOM concentration of the o-LF, i.e. the higher release of the o-LF with the smallest mineral "contamination" (data not shown), we selected $1.8 \mathrm{Mg}$ $\mathrm{m}^{-3}$ and $300 \mathrm{~J} \mathrm{~cm}^{-3}$ for soils from both study areas. Hereafter the soil samples were fractionated according to the following procedure: $125 \mathrm{~cm}^{3}$ of NaPT solution (density $1.8 \mathrm{Mg} \mathrm{m}^{-3}$, soil to solution ratio 1:5) were added to $25 \mathrm{~g}$ of soil, gently shaken and allowed to stand for one hour. After centrifugation at $6800 \mathrm{~g}$ for $20 \mathrm{~min}$, the suspended material ( $\mathrm{f}-\mathrm{LF}<1.8 \mathrm{Mg} \mathrm{m}^{-3}$ ) was separated from the supernatant and filtered on a glass fibre filter (cut-off $0.7 \mu \mathrm{m}$ ) for washing away any residual NaPT. The precipitated material was ultrasonically dispersed in NaPT solution with the same density (1.8 $\mathrm{Mg} \mathrm{m}^{-3}$, soil to solution ratio $\left.1: 5\right)$ by applying $300 \mathrm{~J} \mathrm{~cm}^{-3}$ and allowed to stand for one hour. After centrifugation at $6800 \mathrm{~g}$ for $20 \mathrm{~min}$, the o-LF $<1.8 \mathrm{Mg} \mathrm{m}^{-3}$ was recovered as described above. All three fractions obtained were repeatedly washed with deionised water until the electrical 
conductivity of the supernatant was $<50 \mu \mathrm{S} \mathrm{cm}^{-1}$. They were then oven dried at $50^{\circ} \mathrm{C}$, weighed and analysed for their $\mathrm{C}$ and $\mathrm{N}$ content. Apart from obtaining functionally more homogeneous fractions with a narrower range of properties compared to the bulk soil, this type of density fractionation allows free SOM, and SOM associated with minerals and physically protected into aggregates to be distinguished.

\subsection{Lignin phenols determination}

There is not yet any method able to reliably quantify the total lignin content in soil. Even the cupric oxide $(\mathrm{CuO})$ oxidation, which is perhaps the most widely used method for this purpose, does not succeed in completely depolymerising lignin. It thus cannot be considered as a strictly quantitative method (Kögel, 1986). Nevertheless, $\mathrm{CuO}$ oxidation is able to release phenolic monomers and dimers from the end groups of the lignin macromolecules and, as such, it is a reliable indicator of lignin amount and composition in soil (Otto and Simpson, 2006; Spielvogel et al., 2007; Thevenot et al., 2010). On this basis, we submitted the bulk soil and density fractions to $\mathrm{CuO}$ oxidation according to the modified method proposed by Kögel and Bochter (1985) and Kögel-Knabner (1995). Briefly, 50-200 mg of sample (the higher the C concentration, the lower the quantity of sample), $250 \mathrm{mg} \mathrm{CuO}, 50 \mathrm{mg}$ of glucose, $50 \mathrm{mg}$ of $\mathrm{Fe}\left(\mathrm{NH}_{4}\right)_{2}\left(\mathrm{SO}_{4}\right)_{2} \cdot 6 \mathrm{H}_{2} \mathrm{O}$ and $15 \mathrm{~cm}^{3}$ of $2 M \mathrm{NaOH}$ were digested in a Teflon pot at $172{ }^{\circ} \mathrm{C}$ under $\mathrm{N}_{2}$ atmosphere for $2 \mathrm{~h}$. Afterwards, ethyl vanillin was added as an internal standard to assess the recovery of lignin products. The solution was adjusted to pH $1.8-2.2$ and left overnight for humic acid precipitation. Thereafter, the lignin-derived phenols were purified by elution through $\mathrm{a}_{18}$ column (International Sorbent Technology) and extracted from the column by adding $5 \times 0.5 \mathrm{~cm}^{3}\left(2.5 \mathrm{~cm}^{3}\right.$ in total $)$ ethyl acetate. After evaporating ethyl acetate under $\mathrm{N}_{2}$ flow, the dried residue was dissolved in pyridine containing phenylacetic acid as internal quantification standard, and then derivatised by adding BSTFA $[\mathrm{N}, \mathrm{O}$ bis(trimethylsilyl)trifluoro-acetamide]. The silylated lignin monomers were separated using a HP 6890 gas chromatograph (GC) equipped with a SGE BPX-5 column $(65 \mathrm{~m} \times 0.32 \mathrm{~mm}$ internal 
diameter, $0.25 \mu \mathrm{m}$ film thickness) and a flame ionization detector (FID). The GC oven temperature program was: $100{ }^{\circ} \mathrm{C}(2 \mathrm{~min})$ to $172{ }^{\circ} \mathrm{C}$ at $8^{\circ} \mathrm{C} \min ^{-1}$, to $184{ }^{\circ} \mathrm{C}$ at $4{ }^{\circ} \mathrm{C} \min ^{-1}$, to $300{ }^{\circ} \mathrm{C}$ at $10^{\circ} \mathrm{C}$ $\min ^{-1}$ and $310^{\circ} \mathrm{C}$ for $5 \mathrm{~min}$. Helium was used as carrier gas and samples were injected in split mode (1:10). $\mathrm{CuO}$ oxidation products are composed of vanillyl (V)-units (vanillin, acetovanillone, vanillic acid), syringyl (S)-units (syringaldehyde, acetosyringone, syringic acid), and cinnamyl (C)-units (ferulic and $p$-coumaric acids). The sum of V-, S- and C-type phenols (VSC) was used to estimate the total amount of lignin. $\mathrm{Ac} / \mathrm{Al}_{\mathrm{V}}$ and $\mathrm{Ac} / \mathrm{Al}_{\mathrm{S}}$ are the mass ratios of acid-to-aldehyde for vanillyl and syringyl units, respectively. $\mathrm{S} / \mathrm{V}$ is the mass ratio of syringyl to vanillyl units and $\mathrm{C} / \mathrm{V}$ is the mass ratio of cinnamyl to vanillyl units. These mass ratios are generally used to assess the state of degradation of lignin, since the Ac/Al ratios increase while $\mathrm{S} / \mathrm{V}$ and $\mathrm{C} / \mathrm{V}$ ratios decrease with increasing decomposition. Fire was shown to immediately produce a degraded lignin signature for pure organic matter, increasing the acid-to-aldehyde ratio of V-and S-type units (Nocentini et al., 2010; Rumpel et al., 2007), so partly mimicking the effect of microbial degradation.

\subsection{Non-cellulosic neutral sugars determination}

Sugar monomers were determined according to the method proposed by Amelung et al. (1996) as modified by Rumpel and Dignac (2006). The analysis was performed on both bulk soil and density fractions. Briefly, 200-500 mg of soil, depending on C concentration, were hydrolysed with $4 M$ trifluoroacetic acid (TFA) at $105^{\circ} \mathrm{C}$ for $4 \mathrm{~h}$. After the samples had cooled down, $0.5 \mathrm{~cm}^{3}$ of myoinositol (concentration $2 \mathrm{mg} \mathrm{l}^{-1}$ ) was added as internal standard. Thereafter, the hydrolysed samples were purified by filtration over glass fibre membrane (cut-off $1.2 \mu \mathrm{m}$ ) and dried using a rotary evaporator $\left(58^{\circ} \mathrm{C}\right)$. Ethylenediaminetetraacetic acid (EDTA) was added, according to Eder et al. (2010), to keep iron in solution in a non-reactive form to avoid possible co-precipitation of dissolved organic carbon. Derivatisation of the samples was carried out in screw top test tubes. Aldoses were reduced to their corresponding alditols after addition of $1 \mathrm{~cm}^{3} \mathrm{NaBH}_{4}$ dissolved in dimethyl sulfoxide (DMSO). Acetylation was carried out by adding $2 \mathrm{~cm}^{3}$ acetic anhydride and 2 
$208 \mathrm{~cm}^{3}$ glacial acetic acid, and using methylimidazole $\left(2 \mathrm{~cm}^{3}\right)$ as catalyst. The reaction was stopped 209 after $10 \mathrm{~min}$ by $7 \mathrm{~cm}^{3}$ ice-cold deionized water, which transformed acetic anhydride to acetic acid.

210 The derivatised sugar monomers were extracted by liquid-liquid extraction with $1 \mathrm{~cm}^{3}$ dichloromethane using a vortex mixer. After the phase separation, the darker organic lower phase was removed with a Pasteur pipette and transferred into a GC vial. The analyses were performed by a HP 6890 gas chromatograph (GC) equipped with a SGE BPX-70 column $(60 \mathrm{~m} \times 0.32 \mathrm{~mm}$ internal diameter, $0.25 \mu \mathrm{m}$ film thickness) and a FID. The GC oven temperature program was: $200{ }^{\circ} \mathrm{C}$ to $250^{\circ} \mathrm{C}$ at $8^{\circ} \mathrm{C} \mathrm{m^{-1 }}$ and $250{ }^{\circ} \mathrm{C}$ for $15 \mathrm{~min}$. Helium was used as carrier gas and samples were injected in split mode (1:10).

The TFA digests the monosaccharides originated from plant-deriyed hemicelluloses and microbial products, while it is not able to digest crystalline cellulose (Guggenberger et al., 1994). Hence, hereafter, we will use the term sugars to indicate the non-cellulosic neutral polysaccharides. In particular, the sugar monomers detected by this method are: rhamnose, fucose, ribose, arabinose, xylose, mannose, galactose, glucose. Fructose is transformed into the same alditol as glucose during the reduction step (Rumpel and Dignac, 2006); however, the fructose content in soil is so low that its contribution can be neglected (Amelung et al., 1996). The concentration of individual sugar monomers was calculated based upon the internal standard myoinositol. According to Oades (1984), the proportion of microorganism-derived sugars in relation to plantderived sugars can be roughly estimated by means of the mass ratio of hexoses/pentoses sugars:

$228 \mathrm{GM} / \mathrm{AX}$ ratios are peculiar of carbohydrates predominantly derived from plants and microorganisms, respectively (Oades, 1984).

\section{$2.7 \quad$ Solid-state ${ }^{13}$ C NMR spectroscopy}

232 We analysed by solid-state ${ }^{13} \mathrm{C}$ cross polarisation with magic angle spinning (CP/MAS) nuclear 
234 of the heavy one (HF), which was too poor in $\mathrm{C}$ to provide reliable information (Mastrolonardo et 235 al., 2013). The specimens subjected to NMR analysis were obtained combining equal aliquots of all 236 the independent samples collected from each site. Before ${ }^{13} \mathrm{C}$ NMR analysis, all samples were treated with $2 \%$ hydrofluoric acid, as described by Skjemstad et al. (1994), to remove paramagnetic minerals, which strongly reduce the signal-to-noise ratio of the spectra. NMR spectra were recorded on a Bruker AMX300-WB spectrometer, working at $300.13 \mathrm{MHz}$ for proton and at $75.47 \mathrm{MHz}$ for carbon-13, and equipped with a $4 \mathrm{~mm} \mathrm{CP/MAS} \mathrm{probehead.} \mathrm{The} \mathrm{spectra} \mathrm{were} \mathrm{recorded} \mathrm{with} \mathrm{a}$ contact time of $2 \mathrm{~ms}$ under proton decoupling conditions with a spinning rate of $8 \mathrm{kHz}$. The ${ }^{1} \mathrm{H} 90^{\circ}$ pulse length was $3.4 \mu \mathrm{s}$, the spin-lock field $72 \mathrm{kHz}$, and the recycle delay $4 \mathrm{~s}$. From 4,000 to 40,000 scans were acquired depending on the sample. The chemical shifts were referenced to tetramethylsilane (TMS) using adamantane as external standard.

The contribution of main $\mathrm{C}$ forms to total signal was determined by integration of corresponding chemical shift regions: 0 to $45 \mathrm{ppm}$ (alkyl C), 45 to $110 \mathrm{ppm}(O$-alkyl C, subdivided in methoxyl/ $N$ alkyl C, 45-60 ppm; O-alkyl C, 60-90 ppm; di-O-alkyl C, 90-110 ppm), 110 to 165 ppm (aryl C, subdivided in aromatic $\mathrm{C}-\mathrm{H}$ and $\mathrm{C}-\mathrm{C}, 110-140 \mathrm{ppm}$; O substituted C, 140-165 ppm), 165 to 185 ppm (carboxyl C); no signals arising from aldehydes or ketones were observed in the 185 to 220 ppm region.

\section{$2.8 \quad$ Statistics}

Data from burnt and unburnt soils were compared by two-tailed paired t-test at $95 \%$ confidence level (SigmaPlot 12.0). Where data did not show a normal distribution (Shapiro-Wilk test), Spearman rank correlation was used. 


\subsection{Carbon and nitrogen in the bulk soil}

The measured $\mathrm{pH}$ values, all below 6, demonstrated that the two soils were carbonate-free, hence, that the measured $\mathrm{C}$ was entirely in organic forms. At OR, where fire severity was moderate to high, the concentrations of carbon and nitrogen, and consequently the $\mathrm{C} / \mathrm{N}$ ratios, did not change significantly between the unburnt and burnt soil (Table 2). Perhaps, the fire-induced loss in SOM, if any, was counterbalanced by the input of organic residues, including charcoal, from aboveground biomass and litter. Doing a meta-analysis Johnson and Curtis (2001) found a significant increase in soil $\mathrm{C}$ in the A horizon of forest soils burnt less than 10 years earlier. They attributed such an increase, at least partly, to an accumulation on the ground of unburnt and charred residues. The incorporation of fresh charcoal into the mineral soil at OR is supported by the lower $\delta^{13} \mathrm{C}$ value of the burnt soil compared to the unburnt one (Table 2), since charcoal had lower $\delta^{13} \mathrm{C}$ than unburnt soil (-28.5\%o in charcoal versus $-27.4 \%$ in unburnt soil).

At MG, where fire severity was extremely high, the burnt soil exhibited substantially lower C and N concentrations compared to the unburnt one: 88 and $164 \mathrm{~g} \mathrm{C} \mathrm{kg}^{-1}$, and 4.3 and $5.8 \mathrm{~g} \mathrm{~N} \mathrm{~kg}^{-1}$, respectively (Table 2). Such fire-induced losses are out of range when compared to data reported by Nave et al. (2011) in their meta-analysis. At MG, also the $\mathrm{C} / \mathrm{N}$ ratio experienced a significant decrease, which might be explained by an accumulation of recalcitrant organic $\mathrm{N}$-forms in the charred material (Almendros et al., 2003; González-Pérez et al., 2004; Mastrolonardo et al., 2014; Santin et al., 2008). The addition of any charred materials from the aboveground biomass at MG was evidently not sufficient to counterbalance the large loss of SOM. Nevertheless, it should be noted that the surface ash layer removed during sampling to expose the mineral soil was considerable (1.7 $\mathrm{cm}$ thick on average). It contained substantial amounts of $\mathrm{C}\left(62 \mathrm{~g} \mathrm{~kg}^{-1}\right)$, mainly in the form of charcoal (Santin et al., 2012). Although the ash layer does usually not remain on hillslopes for a long time because of wind and water erosion (Bodì et al., 2014; Rumpel et al., 2009), it is conceivable that over time, at least some of the $\mathrm{C}$ retained in the ash layer would become incorporated into the mineral soil and hence increase the $\mathrm{C}$ content in the mineral soil. 


\subsection{Carbon and nitrogen in density fractions}

287 The $\mathrm{C}$ and $\mathrm{N}$ concentrations of soil density fractions are given in Table 2. Light fractions, $\mathrm{f}-$ and o-

LF, are generally assumed to comprise mainly plant debris and ancillary animal residues, charcoal and microorganisms colonising organic residues (Golchin et al., 1994; Wagai et al., 2009). Their main differences generally are in the particle size and location within the soil matrix: the f-LF is assumed to feature larger almost undecomposed organic materials, while the o-LF should comprise finer and more altered organic particles than the f-LF (Cerli et al., 2012; Golchin et al., 1994). The $\mathrm{C} / \mathrm{N}$ ratio of density fractions of the unburnt soil at both OR and MG supports the expectation that SOM ranges between the less degraded light fractions, having a higher $\mathrm{C} / \mathrm{N}$, to the comparably more decomposed heavy fraction showing a lower $\mathrm{C} / \mathrm{N}$. These considerations are consistent with the higher ${ }^{13} \mathrm{\delta} \mathrm{C}$ values for HF compared to light fractions, which support the hypothesis of a higher decomposition of the former fraction (Roscoe et al., 2001). In spite of low $\mathrm{C}$ and $\mathrm{N}$ concentrations, but due to its large relative mass (Table 2), HF stores one third of total SOC and almost half of total soil N (Fig. 2). Comparing density fractions from burnt and unburnt soils, it could be inferred if and how the aggregates were able to protect SOM from heating and if they collapsed because of fire. As quite recently reviewed by Mataix-Solera et al. (2011), the response of soil aggregates to heating by fire can be highly variable. Fire can oxidise organic binding agents in aggregates thereby causing their breakdown. Alternatively, a fast vaporisation of the water included in aggregates can lead to their destruction in a similar way as slacking does (Albalasmeh et al., 2013). However, under certain conditions, i.e. for wettable soils with SOM as main binding agent subject to low severity fires, aggregate stability may improve as a consequence of enhanced soil water repellency (MataixSolera and Doerr, 2004).

At OR, fire apparently caused an increase of $\mathrm{C}$ and $\mathrm{N}$ stock and concentration of f-LF (Table 2; Fig. 2). This increase is probably due to the incorporation of some charred residues into the top centimetres of soil and the charring of part of SOM there present. The C stock in the o-LF was 
slightly lower in the burnt soil compared to the unburnt one, although the $\mathrm{C}$ and $\mathrm{N}$ concentrations were actually higher (Fig 2; Table 2). This leads us to hypothesise that fire could have actually caused a partial disruption of aggregates; these latter released some high density mineral particles with no or little interaction with $\mathrm{OM}$ and some OM free particles, which may might have become part of the HF and the f-LF, respectively (Fig. 3). The so released SOM might also be more exposed to decomposition because more easily accessible by microorganisms and their enzymes. The same phenomenon, some fire-induced aggregate disruption, also occurred at MG, here resulting overall in an increase of the HF (Table 2). However, at MG the most affected fraction was the f-LF, that experienced a depletion in the $\mathrm{C}$ and $\mathrm{N}$ content and contribution (Table 2; Fig. 2).

\subsection{Soil polysaccharides content}

At OR, neutral sugars in the burnt and unburnt soils amounted to 7.4 and $8.2 \mathrm{~g} \mathrm{~kg}^{-1}$, respectively, which correspond to 76 and $97 \mathrm{~g} \mathrm{~kg}^{-1}$ of SOC (Table 3), in the range of data reported by other authors for forest soils (e.g., Guggenberger et al., 1994; Rumpel and Dignac, 2006). The apparent fire-induced decrease in neutral sugars was statistically significant if referred to total SOC, but not in absolute terms. The GM/AX ratio before fire occurrence was $>2$, indicating that sugars were synthetized mainly by microbial population (Guggenberger and Zech, 1994; Oades, 1984). Fire did not change this ratio indicating that, in principle, neither plant- nor microbial-derived sugars were preferentially affected by fire.

The SOC normalised sugar content slightly decreased due to fire in the f-LF, while in the other fractions, o-LF and HF, it increased (Table 3). A possible explanation for this result could be that sugars associated to minerals were relatively preserved compared to the other OM compounds. In fact, it is commonly reported that sugars of microbial origins contribute to the formation and stabilisation of soil aggregates, hence benefiting from physical protection. Moreover, they seem to be chemically stabilised by interaction with the mineral phase (Kiem and Kögel-Knabner, 2003; Martín et al., 2009; Rumpel et al., 2010). 
At MG, the absolute concentration of non-cellulosic neutral polysaccharides in the bulk soil was substantially lower in the burnt area than in the unburnt one: 9 and $21 \mathrm{~g} \mathrm{~kg}^{-1}$, respectively. This apparent decrease, however, was not significant if sugar content was normalised to SOC (Table 3). This suggests that the polysaccharides present in the mineral soil were not preferentially affected by fire, despite being part of the most thermally labile SOM pool (De la Rosa et al., 2008). However, it must be pointed out that the method we used is not able to also detect cellulose $\mathrm{C}$, which may have a different behaviour towards fire compared to non-cellulosic sugars. Like at OR, the GM/AX ratio at MG indicates approximately that carbohydrates were mainly originated from microorganisms and the ratio did not change after fire occurrence. Most of the sugars were stored in the f-LF and were apparently greatly lost because of the fire, in the former fraction as well as in the HF and o-LF, both in absolute terms (normalised to mass proportion of density fractions) and relative to SOC (Table 3).

\subsection{Soil lignin content}

At $\mathrm{OR}$, the yield of phenolic $\mathrm{CuO}$ oxidation products in the burnt soil was significantly lower than in the unburnt one, both in absolute terms and relative to SOC (Table 4). This suggests that lignin was somehow preferentially affected by fire, despite its assumed moderate recalcitrance to heating (Knicker et al., 2005). Fire apparently left the VSC content of SOC associated to HF almost unaltered, while it affected the VSC content of the light fractions, particularly o-LF, both in absolute value and relative to SOC. Therefore, occlusion into aggregates does not seem to guarantee lignin protection. Even, pyrolytic degradation of lignin polymers in aggregates could be favoured by inorganic catalysts, such as acidic clay minerals (Ohta and Venkatesan, 1992).

At MG, the absolute yield of phenolic $\mathrm{CuO}$ oxidation monomers was half in the burnt bulk soil compared to the unburnt one (Table 4), but such a difference was inconsistent if values were referred to SOC. As in the case of sugars, lignin monomers did not appear to be preferentially affected by fire compared to other SOM constituents. In the unburnt soil, lignin absolute content 
was almost equally distributed among density fractions. Fire mainly affected the f-LF, causing large decrease in its VSC content. The o-LF showed the highest lignin contribution to SOC and the highest apparent lignin loss due to fire, while HF even shows a relative accumulation of lignin compounds.

At both study sites, none of the indicators describing the composition and degradation of lignin, i.e. acid-to-aldehyde ratios of V and S-type units, S-to-V and C-to-V ratios, changed significantly in response to fire (Table 4). Hence, it seems that fire affected unselectively all lignin units, which is in contrast to what has been reported by other authors, i.e. a higher thermal susceptibility of aldehydes in V and S phenols (Certini et al., 2011; Kuo et al., 2008; Nocentini et al., 2010; Ohta and Venkatesan, 1992; Rumpel et al., 2007).

Plotting the sugar vs. lignin contents from burnt soils at OR and MG, we found a fairly good linear correlation that did not occur in the unburnt soils (Fig. 4). This correlation probably depends on fire that, whatever its severity, would affect lignin and sugars leading to an overall decrease of both of them. Although based on a relatively small sample size here, this intriguing correlation deserves further investigation in future studies to ascertain its wider validity.

\subsection{NMR analysis}

The ${ }^{13} \mathrm{C}$ CPMAS NMR spectra of bulk soil from burnt and unburnt areas at OR and MG are displayed in Fig. 5, while Table 5 shows the percent distribution of the total signal among seven chemical shift regions. The most evident difference between the burnt and unburnt soil specimens was the more intense signal of the former in the aromatic $\mathrm{C}$ region $(110-160 \mathrm{ppm})$. This was clearly due to some input of charred material, whose signal is centred at 130 ppm (Skjemstad et al., 1996). At OR, this enrichment was counterbalanced by a decrease in alkyl-C (0-45 ppm region) and a less substantial decrease in $O$-alkyl C (60-90 ppm). The two sharp peaks at around 72 and $104 \mathrm{ppm}$ in the burnt soil revealed the persistence of substantial amounts of polysaccharides, possibly cellulose. Therefore, contrary to what is commonly found (e.g., Certini et al., 2011; Knicker et al., 2005, 
2006), here $O$-alkyl C does not seem to be the most fire-affected C form. At MG, in spite of the extremely high fire severity, spectra did not show major differences, apart from the evident enrichment in aromatic $\mathrm{C}$ in the burnt soil. Both burnt and unburnt soils were characterised by dominant signals in the alkyl $\mathrm{C}$ region, generally assigned to lipids and other aliphatic compounds, and in the $O$-alkyl $\mathrm{C}$ region, indicative for polysaccharides and amide $\mathrm{C}$ of proteins (Knicker and Lüdemann, 1995). The decrease in intensities of these signals, plausibly attributable to fire, is modest.

The NMR spectra of the light density fractions from OR and MG are shown in Fig. 6 and 7, while the signal distribution among the chemical shift regions of the spectra is in Table 5 . The light fractions from the unburnt soils had similar patterns in the two sites, although the o-LF revealed more advanced stage of alteration than $\mathrm{f}-\mathrm{LF}$, as chiefly indicated by a lower $O$-alkyl C to alkyl C ratio (Baldock et al., 1992) and a much higher signal in the aryl C region (Golchin et al., 1994). In particular, the higher relative intensity observed in the aromatic region at $~ 150,130$ and $115 \mathrm{ppm}$ for o-LF with respect to f-LF suggests higher lignin content (Golchin et al., 1994; Hatcher, 1987). The NMR analysis unravelled that in both soils the light fractions were to some extent affected by fire at both sites (Figs. 6 and 7). At OR, the f-LF from the burnt soil showed higher intensity of the peak at $130 \mathrm{ppm}$, and smaller signals in the alkyl (0-45 ppm), $O$-alkyl (60-90 ppm) and carboxyl C (160-185) regions compared to the counterpart from the unburnt soil, overall indicating charring processes. In the o-LF, the peak at $56 \mathrm{ppm}$ (ascribable to lignin methoxyl carbon) and the signal at around $150 \mathrm{ppm}(O$-substituted phenolic carbon) decreased much in the burnt soil compared to the unburnt one, which suggests lignin decomposition. At MG, the most evident fire-induced change to light fractions of SOC was the increase of the peak at $130 \mathrm{ppm}$, while ancillary differences are the decrease of the peaks at about 150 and 53 (lignin), and the intensification of the peak at $174 \mathrm{ppm}$ (carboxylic C). This latter was unexpected, because organic matter exposed to severe heating generally loses carboxyl C (Knicker et al., 2005). 


\section{Conclusions}

Our parallel investigation at Orentano and Mt. Gordon, two areas recently affected by wildfires of markedly different severity, showed that in both cases fire had a marked impact on composition of SOM from the uppermost mineral soil. This impact was partly independent of fire severity. At Orentano, Italy, where fire severity in the mixed oak-pine forest was moderate, soil did not experience any significant, loss of carbon. On the contrary, some charred material from the organic layer and the standing vegetation had joined the mineral soil. At Mt. Gordon, Australia, where the eucalypt forest had been burnt by an extremely severe fire, SOM experienced substantial loss not counterbalanced by the incorporation of charred materials, although it is likely that over time some of the OM still retained in the ash layer will be partly incorporated into the mineral soil.

Density fractionation enabled to examine three SOM pools with different characteristics and turnover time in soil, and to assess the fire impact on each of them. In spite of contrasting fire severity, at the two study sites we found similar fire impacts on the SOM assumed occluded in aggregates. Apparently, fire partly disrupted aggregates, causing release of SOM from this fraction. Such a SOM redistribution could imply substantial changes to $\mathrm{C}$ cycle. It is reasonable, for example, to assume higher availability of the released SOM to microorganisms. This outcome of fire should be taken into account, together with the significant immediate loss of SOM due to combustion and the increase in mean residence time of charred residues, when accounting for the fire impact on $\mathrm{C}$ balances.

In terms of SOM composition, at OR lignin was preferentially affected by fire compared to sugars, particularly in the light fraction occluded into aggregates, where presumably minerals offered different protection to different compounds. At MG, where lignin and sugars decreased a lot in response to fire occurrence, apparently none of the main $\mathrm{C}$ forms were preferentially affected by fire, either in the bulk SOM or the density fractions. Variables formerly proposed as reliable indicators of fire severity in soil, i.e. the sugar-to-total organic $\mathrm{C}$ ratio and phenols ratio in lignin, did not provide encouraging results in this study. Further studies are needed to elucidate the 
441 complex impact of fire on SOM composition and to ultimately identify the chemical legacies that 442 are most useful to reconstruct fire history.

\section{Acknowledgments}

446 The work of the first author, G.M., was supported by a mobility fellowship provided by the 447 European Science Foundation (Ref. number: 3690) under the framework of the MOLTER Program 448 (MOLecular structures as drivers and tracers of TERrestrial C fluxes). For site MG, sample 449 collection and analysis were supported by a UK Natural Environment Research Council Urgency 450 Grant (NE/F00131X/1). Patrick Lane, Petter Nyman, Richard Shakesby, Gary Sherdian and Hugh 451 Smith supported sample collection in Australia. We are also indebted to Gianluca Borgogni, who 452 kindly drew Figure 3.

\section{References}

455 Albalasmeh, A.A., Berli, M., Shafer, D.S., Ghezzehei, T.A., 2013. Degradation of moist soil aggregates by rapid temperature rise under low intensity fire. Plant and Soil 362, 335-344. 2010. Thermal alteration of organic matter during a shrubland fire: A field study. Organic

$$
\text { Geochemistry 41, 690-697. }
$$

Almendros, G., Knicker, H., González-Vila, F.J., 2003. Rearrangement of carbon and nitrogen forms in peat after progressive thermal oxidation as determined by solid-state ${ }^{13} \mathrm{C}$-and ${ }^{15} \mathrm{~N}-\mathrm{NMR}$ spectroscopy. Organic Geochemistry 34, 1559-1568.

Amelung, W., Cheshire, M.V., Guggenberger, G., 1996. Determination of neutral and acidic sugars in soil by capillary gas-liquid chromatography after trifluoroacetic acid hydrolysis. Soil Biology and Biochemistry 28, 1631-1639. 
Baldock, J., Oades, J., Waters, A., Peng, X., Vassallo, A., Wilson, M., 1992. Aspects of the chemical structure of soil organic materials as revealed by solid-state ${ }^{13} \mathrm{C}$ NMR spectroscopy. Biogeochemistry 16, 1-42.

Bento-Gonçalves, A., Vieira, A., Úbeda, X., Martin, D., 2012. Fire and soils: Key concepts and recent advances. Geoderma 191, 3-13.

Bodí, M.B., Martin, D.A., Balfour, V.N., Santín, C., Doerr, S.H., Pereira, P., Cerdá, A., MataixSolera, J., 2014. Wildland fire ash: Production, composition and eco-hydro-geomorphic effects. Earth Science Reviews 130, 103-127.

Cerli, C., Celi, L., Bosio, P., Motta, R., Grassi, G., 2009. Effects of land use change on soil properties and carbon accumulation in the Ticino Park (North Italy). Studi Trentini di Scienze Naturali 85, 83-92.

Cerli, C., Celi, L., Kalbitz, K., Guggenberger, G., Kaiser, K., 2012. Separation of light and heavy organic matter fractions in soil-Testing for proper density cut-off and dispersion level. Geoderma 170, 403-416.

Certini, G., 2005. Effects of fire on properties of forest soils: a review. Oecologia 143, 1-10.

Certini, G., Nocentini, C., Knicker, H., Arfaioli, P., Rumpel, C., 2011. Wildfire effects on soil organic matter quantity and quality in two fire-prone Mediterranean pine forests. Geoderma 167, $148-155$.

Chafer, C., Noonan, M., Macnaught, E., 2004. The post-fire measurement of fire severity and intensity in the Christmas 2001 Sydney wildfires. International Journal of Wildland Fire 13, $227-240$

De la Rosa, J.M., López-Capel, E., Manning, D., González-Perez, J.A., González-Vila, F.J., 2008. Direct detection of black carbon in soils by Py-GC/MS, carbon-13 NMR spectroscopy and thermogravimetric techniques. Soil Science Society of America Journal 72, 258-268.

DeBano, L.F., 1991. The effect of fire on soil properties. General Technical Report - US Department of Agriculture, Forest Service. 
Eder, E., Spielvogel, S., Kölbl, A., Albert, G., Kögel-Knabner, I., 2010. Analysis of hydrolysable neutral sugars in mineral soils: Improvement of alditol acetylation for gas chromatographic separation and measurement. Organic Geochemistry 41, 580-585.

Egli, M., Mastrolonardo, G., Seiler, R., Raimondi, S., Favilli, F., Crimi, V., Krebs, R., Cherubini, P., Certini, G., 2012. Charcoal and stable soil organic matter as indicators of fire frequency, climate and past vegetation in volcanic soils of Mt. Etna, Sicily. Catena 88, 14-26.

Golchin, A., Baldock, J.A., Clarke, P., Higashi, T., Oades, J.M., 1997. The effects of vegetation and burning on the chemical composition of soil organic matter of a volcanic ash soil as shown by ${ }^{13}$ C NMR spectroscopy. II. Density fractions. Geoderma 76, 175-192.

Golchin, A., Oades, J., Skjemstad, J., Clarke, P., 1994. Study of free and occluded particulate organic matter in soils by solid state ${ }^{13} \mathrm{C} C \mathrm{CP} / \mathrm{MAS}$ NMR spectroscopy and scanning electron microscopy. Soil Research 32, 285-309.

González-Pérez, J.A., González-Vila, F.J., Almendros, G., Knicker, H., 2004. The effect of fire on soil organic matter - a review. Environment International 30, 855-870.

Guggenberger, G., Christensen, B.T.,Zech,W., 1994. Land-use effects on the composition of organic matter in particle-size separates of soil: I. Lignin and carbohydrate signature. European Journal of Soil Science 45, 449-458.

Guggenberger, G., Zech, W., 1994. Composition and dynamics of dissolved carbohydrates and lignin-degradation products in two coniferous forests, N.E. Bavaria, Germany. Soil Biology and Biochemistry 26, 19-27.

Hatcher,P.G., 1987. Chemical structural studies of natural lignin by dipolar dephasing solid-state 13C nuclear magnetic resonance. Organic Geochemistry 11, 31-39.

Hernández, T., Garcia, C., Reinhardt, I., 1997. Short-term effect of wildfire on the chemical, biochemical and microbiological properties of Mediterranean pine forest soils. Biology and Fertility of Soils 25, 109-116. 
IUSS Working Group WRB, 2014. World Reference Base for Soil Resources 2014. International soil classification system for naming soils and creating legends for soil maps. World Soil Resources Reports No. 106. FAO, Rome.

Johnson, D.W., Curtis, P.S., 2001. Effects of forest management on soil C and N storage: meta analysis. Forest Ecology and Management 140, 227-238.

Kiem, R., Kögel-Knabner, I., 2003. Contribution of lignin and polysaccharides to the refractory carbon pool in C-depleted arable soils. Soil Biology and Biochemistry 35, 101-118.

Knicker, H., 2007. How does fire affect the nature and stability of soil organic nitrogen and carbon? A review. Biogeochemistry 85,91-118.

Knicker, H., 2011. Pyrogenic organic matter in soil: Its origin and occurrence, its chemistry and survival in soil environments. Quaternary International 243, 251-263.

Knicker, H., Almendros, G., González-Vila, F.J., González-Pérez, J.A., Polvillo, O., 2006.

Characteristic alterations of quantity and quality of soil organic matter caused by forest fires in continental Mediterranean ecosystems: a solid-state ${ }^{13} \mathrm{C}$ NMR study. European Journal of Soil Science 57, 558-569.

Knicker, H., González-Vila, F.J., Polvillo, O., González-Pérez, J.A., Almendros, G., 2005. Fireinduced transformation of $\mathrm{C}$ - and $\mathrm{N}$ - forms in different organic soil fractions from a Dystric Cambisol under a Mediterranean pine forest (Pinus pinaster). Soil Biology and Biochemistry 37 , $701-718$.

Knicker, H., Lüdemann, H-D., 1995. N-15 and C-13 CPMAS and solution NMR studies of N-15 enriched plant material during 600 days of microbial degradation. Organic Geochemistry 23, $329-341$.

Kögel, I., 1986. Estimation and decomposition pattern of the lignin component in forest humus layers. Soil Biology and Biochemistry 18, 589-594. 
541 Kögel, I., Bochter, R., 1985. Characterization of lignin in forest humus layers by high-performance 542 liquid chromatography of cupric oxide oxidation products. Soil Biology and Biochemistry 17, $543 \quad 637-640$.

544 Kögel-Knabner, I., 1995. Composition of soil organic matter. In: Alef K., Nannipieri P., (eds) 545 Methods in Applied Soil Microbiology and Biochemistry. Academic Press, London, pp. 66-121. 546 Kuhlbusch, T.A.J., Crutzen, P.J., 1995. Toward a global estimate of black carbon in residues of 547 vegetation fires representing a sink of atmospheric $\mathrm{CO}_{2}$ and a source of $\mathrm{O}_{2}$. Global $548 \quad$ Biogeochemical Cycles 9, 491-501.

549 Kuo, L.J., Louchouarn, P., Herbert, B.E., 2008. Fate of CuO-derived lignin oxidation products 550 during plant combustion: Application to the evaluation of char input to soil organic matter. $551 \quad$ Organic Geochemistry 39, 1522-1536.

Lavorel, S., Flannigan, M.D., Lambin, E.F., Scholes, M.C., 2007. Vulnerability of land systems to 553 fire: Interactions among humans, climate, the atmosphere, and ecosystems. Mitigation and $554 \quad$ Adaptation Strategies for Global Change 12, 33-53.

555 Martín, A., Díaz-Raviña, M., Carballas, T., 2009. Evolution of composition and content of soil 556 carbohydrates following forest wildfires. Biology and Fertility of Soils 45, 511-520.

557 Mastrolonardo, G., Certini, G., Krebs, R., Forte, C., Egli, M., 2013. Effects of fire on soil organic 558 matter quality along an altitudinal sequence on Mt. Etna, Sicily. Catena 110, 133-145.

559 Mastrolonardo, G., Francioso, O., Di Foggia, M., Bonora, S., Rumpel, C., Certini, G., 2014. 560 Application of thermal and spectroscopic techniques to assess fire-induced changes to soil 561 organic matter in a Mediterranean forest. Journal of Geochemical Exploration 143, 174-182. 562 Mataix-Solera, J., Cerdà, A., Arcenegui, V., Jordán, A., Zavala, L.M., 2011. Fire effects on soil 563 aggregation: A review. Earth-Science Reviews 109, 44-60.

564 Mataix-Solera, J., Doerr, S., 2004. Hydrophobicity and aggregate stability in calcareous topsoils 565 from fire-affected pine forests in southeastern Spain. Geoderma 118, 77-88. 
566 McCaw, L., Sullivan, A., Mills, G., Pippen, B., Balch, J., Ellis, P., Matthews, S., Plucinski, M., 567 Hurley, R., 2009. Chapter 1: Fire Behaviour Investigation, in: Research Results from February 568 7th 2009 Victorian Fires. Final Bushfire CRC Report, Bushfire Cooperative Research Centre, 569 Melbourne, Australia.

570 Nave, L.E., Vance, E.D., Swanston, C.W., Curtis, P.S., 2011. Fire effects on temperate forest soil C 571 and N storage. Ecological Applications 21, 1189-1201.

572 Neary, D.G., Klopatek, C.C., DeBano, L.F., Ffolliott, P.F., 1999. Fire effects on belowground 573 sustainability: a review and synthesis. Forest Ecology and Management 122, 51-71

574 Nocentini, C., Certini, G., Knicker, H., Francioso, O., Rumpel, C., 2010. Nature and reactivity of 575 charcoal produced and added to soil during wildfire are particle-size dependent. Organic 576 Geochemistry 41, 682-689.

577 Oades, J.M., 1984. Soil organic matter and structural stability: mechanisms and implications for 578 management. Plant and Soil 76, 319-337.

579 Ohta, K., Venkatesan, M.I., 1992. Pyrolysis of wood specimens with and without minerals: 580 implications to lignin diagenesis. Energy Fuels 6, 271-277.

581 Otto, A., Simpson, M.J., 2006. Evaluation of $\mathrm{CuO}$ oxidation parameters for determining the source 582 and stage of lignin degradation in soil. Biogeochemistry 80, 121-142.

583 Roscoe, R., Buurman, P., Velthorst, E.J., Vasconcellos, C.A., 2001. Soil organic matter dynamics in 584 density and particle size fractions as revealed by the ${ }^{13} \mathrm{C} /{ }^{12} \mathrm{C}$ isotopic ratio in a Cerrado's oxisol. $585 \quad$ Geoderma 104,185-202.

586 Royal Commission, 2009. Victorian Bushfire Royal Commission - Interim Report. Chapter 1: The 587 February 2009 Fires. Parliament of Victoria, 2009 Victorian Bushfires Royal Commission. 588 Rumpel, C., Ba, A., Darboux, F., Chaplot, V., Planchon, O., 2009. Erosion budget and process 589 selectivity of black carbon at meter scale. Geoderma 154, 131-137. 
590 Rumpel, C., Dignac, M.-F., 2006. Gas chromatographic analysis of monosaccharides in a forest soil 591 profile: Analysis by gas chromatography after trifluoroacetic acid hydrolysis and reduction592 acetylation. Soil Biology and Biochemistry 38, 1478-1481.

593 Rumpel, C., Eusterhues, K., Kögel-Knabner, I., 2010. Non-cellulosic neutral sugar contribution to 594 mineral associated organic matter in top- and subsoil horizons of two acid forest soils. Soil $595 \quad$ Biology and Biochemistry 42, 379-382.

596 Rumpel, C., González-Pérez, J.A., Bardoux, G., Largeau, C., Gonzalez-Vila, F.J., Valentin, C., 597 2007. Composition and reactivity of morphologically distinct charred materials left after slash598 and-burn practices in agricultural tropical soils. Organic Geochemistry 38, 911-920.

599 Santin, C., Knicker, H., Fernandez, S., Menendezduarte, R., Alvarez, M., 2008. Wildfires influence 600 on soil organic matter in an Atlantic mountainous region (NW of Spain). Catena 74, 286-295.

601 Santin, C., Doerr, S.H., Shakesby, R.A., Bryant, R., Sheridan, G.J., Lane, P.N.J., Smith, H.G., Bell, 602 T.L., 2012. Carbon forms and sequestration potential within ash deposits from forest fires: new 603 insights from the 2009 'Black Saturday' fires, Australia. European Journal of Forest Research $604 \quad 131,1245-1253$.

605 Scott, A.C, Bowman, D.M.J.S., Bond, W.J., Pyne, S.J., Alexander, M.E., 2014. Fire on Earth: An 606 Introduction. Wiley, Oxford, UK.

607 Shakesby, R.A., Doerr, S.H., 2006. Wildfire as a hydrological and geomorphological agent. Earth608 Science Reviews 74,269-307.

609 Schmidt, M., Rumpel, C., Kögel-Knabner, I., 1999. Particle size fractionation of soil containing $610 \quad$ coal and combusted particles. European Journal of Soil Science 50, 515-522.

611 Schmidt, M.W.I., Noack, A.G., 2000. Black carbon in soils and sediments: Analysis, distribution, 612 implications, and current challenges. Global Biogeochemical Cycles 14, 777-793.

613 Sharma, R.K., Wooten, J.B., Baliga, V.L., Lin, X., Geoffrey Chan, W., Hajaligol, M.R., 2004. 614 Characterization of chars from pyrolysis of lignin. Fuel 83, 1469-1482. 
615 Skjemstad, J., Clarke, P., Taylor, J., Oades, J., Newman, R., 1994. The removal of magnetic 616 materials from surface soils-a solid state ${ }^{13} \mathrm{C} \mathrm{CP} / \mathrm{MAS}$ NMR study. Australian Journal of Soil $617 \quad$ Research 32, 1215-1229.

618 Skjemstad, J.O., Clarke, P., Taylor, J.A., Oades, J.M., McClure, S.G., 1996. The chemistry and 619 nature of protected carbon in soil. Australian Journal of Soil Research 34, 251-271.

620 Sohi, S.P., Mahieu, N., Arah, J.R.M., Powlson, D.S., Madari, B., Gaunt, J.L., 2001. A procedure for 621 isolating soil organic matter fractions suitable for modeling. Soil Science Society American 622 Journal 65, 1121-1128.

623 Spielvogel, S., Prietzel, J., Kögel-Knabner, I., 2007. Changes of lignin phenols and neutral sugars in 624 different soil types of a high-elevation forest ecosystem 25 years after forest dieback. Soil 625 Biology and Biochemistry 39, 655-668.

626 Thevenot, M., Dignac, M.-F., Rumpel, C., 2010. Fate of lignins in soils: A review. Soil Biology and $627 \quad$ Biochemistry 42, 1200-1211.

628 Wagai, R., Mayer, L.M., Kitayama, K., 2009. Nature of the "occluded" low-density fraction in soil 629 organic matter studies: A critical review. Soil Science and Plant Nutrition 55, 13-25.

630 